Egyptian Journal of Aquatic Biology \& Fisheries

Zoology Department, Faculty of Science,

Ain Shams University, Cairo, Egypt.

ISSN $1110-6131$

Vol. 22(5): 1- 21 (2018)

ejabf.journals.ekb.eg

\title{
GC/MS identification and applications of bioactive seaweed extracts from Mediterranean coast of Egypt
}

\author{
Sahar W. M. Hassan ${ }^{1}$ and Aida H. Shobier ${ }^{2 *}$ \\ 1- Marine Microbiology Lab, Division of Marine Environment, National Institute of \\ Oceanography and Fisheries, Egypt \\ 2- Marine Pollution Lab, Division of Marine Environment, National Institute of \\ Oceanography and Fisheries, Egypt
}

\begin{abstract}
ARTICLE INFO
Article History:

Received: Sept. 21,2018

Accepted: Oct. 14, 2018

Available online:Oct.25, 2018

Keywords:

C. sinuosa

C. officinalis

$n$-Hexadecanoic acid

Encapsulation

Antibacterial activity

Antifouling activity
\end{abstract}

\begin{abstract}
The antibacterial activity of different seaweed species against five fish pathogens (A. hydrophila, V. parahaemolyticus, V. alginolyticus, V. damsela and Vibrio sp.) has been evaluated. The ethanolic extract of $C$. sinuosa (CSE1) and dichloromethane extract of $C$. officinalis (COM) exhibited the highest antibacterial activity with activity index $(\mathrm{AI})=1.4 \pm 0.74$ and $1.2 \pm 0.71$, respectively. When the extracts were encapsulated into calcium alginate beads their antibacterial activity against the most susceptible bacterial pathogens showed that the significant growth inhibition was against $V$. parahaemolyticus after $5 \mathrm{~min}$ post addition of the beads recording 1.4 and 2 fold decrease in the growth, respectively. Recycling of the $(\mathrm{CA} / \mathrm{COM})$ beads was carried out for 7 successive cycles with success in elimination of $V$. parahaemolyticus. The potential applications of encapsulated extracts for elimination of microbial load in fish rearing water and antifouling activity were proved in the current investigation. The chemical composition of the bioactive extracts (CSE1) and (COM) was determined using GC/MS analysis which revealed the presence of several constituents that have been reported to exhibit antimicrobial activity. Additionally, the dichloromethane extract (COM) produced six major components including n-nonadecane, 1,2,3propanetricarboxylic acid, 2-(acetyloxy)-, tributyl ester, 2-methylhexadecan-1-ol, 1-docosene, 1-eicosanol and chloroacetic acid, octadecyl ester. However, the ethanolic extract (CSE1) was characterized by the presence of fatty acids, fatty acids ethyl esters and aromatic hydrocarbon where the most abundant compound was $n$-tridecanoic acid ethyl ester.
\end{abstract}

\section{INTRODUCTION}

Adverse effects of infectious diseases on global aquaculture are alarming since they cause total or partial loss of production (FAO, 2016; Bondad-Reantaso et al., 2005; Ward et al., 2016). It is well known that fishes are harmful carriers of some infectious diseases leading to opportunistic microorganisms such as Salmonella and Vibrio species. In order to get over these problems, synthetic chemicals and nonbiodegradable polymers have been used to control the infections. Accumulated chemicals can cause environmental pollution, which may be toxic to the non-target organisms (Randhawa \& Kullar, 2011). Moreover, commercial use of antibiotics and veterinary drugs are limited for use in aquaculture to control the bacterial and other opportunistic infections. Currently, degradable natural compounds from biochemical origin are used as an eco-friendly approach in aquaculture for the control of infection and thus promote growth (Stalin et al., 2008). 
Seaweeds are rich in bioactive compounds that are safe and nontoxic compared with chemical synthetic drugs (Fernando et al., 2018; Wang et al., 2018). Recently, majority of potential antibacterial natural products are produced from marine resources (Goyal et al., 2017; Nalini et al., 2018). Seaweed extracts or their isolated components have been utilized for treatment and/or prevention of shrimp and fish diseases (Chakraborty et al., 2014; Tomazelli Jr. et al., 2017) because of their nutritional, immunomodulatory, antiviral, antibacterial, and growth promoting activities (Cruz-Suárez et al., 2008; Fleurence et al., 2012; Milledge et al., 2016; Pádua et al., 2015; Sanjeewa et al., 2016). Encapsulation has been used for the protection of natural molecules against environmental conditions (Azzi et al., 2017; Gharib et al., 2017). The encapsulation of bioactive agents may enhance their solubility, stability, efficiency, and bioavailability as well as control their release (Parris et al., 2005; Ephrem et al., 2018). Alginate microbeads have been used for the encapsulation of both low molecular and macromolecular weight agents (Ephrem et al., 2018; Kavoosi et al., 2018).

Biofouling process takes place when any natural or artificial surfaces submerged into the marine environment and colonized by micro- and macroorganisms (Clare, 1996), which in turn causes major ecological and economic impacts, especially when it occurs on ship hulls or aquaculture facilities (Yebra et al., 2004; Piola et al., 2009). Since several commercial biocides such as TBT based antifouling paints have been recently banned, the screening for alternative ecofriendly antifoulants appears to be urgent (Dobretsov et al., 2015). Seaweeds could be an important source, since they produce metabolites such as amides, fatty acids, terpenoids, pyrroles, lactones and steroids with antifouling potential.

The present investigation is focused on the study of the antibacterial activity of hexane, dichloromethane and ethanolic extracts of five Mediterranean seaweeds belong to Chlorophyta (Ulva fasciata, Ulva linza), Rhodophyta (Corallina officinalis, Jania rubens) and Phaeophyta (Colpomenia sinuosa)) collected from the coast of Alexandria (Egypt) against five fish pathogens (A. hydrophila, V. parahaemolyticus, $V$. alginolyticus, $V$. damsela and Vibrio sp.). The bioactive components of dichloromethane and ethanolic extracts from $C$. officinalis and $C$. sinuosa, respectively were investigated using gas chromatography/mass spectroscopy (GC/MS) analysis. The effect of the encapsulation process and other potential applications of both extracts have been investigated.

\section{MATERIALS AND METHODS}

\section{Seaweed collection}

The five seaweed species used in this study; Ulva fasciata, Ulva linza, Corallina officinalis, Jania rubens and Colpomenia sinuosa were collected from the coast of Alexandria, Egypt at Abu Qir Bay and the Eastern Harbour (El-Manshia). Seaweeds were identified according to Aleem (1993). After collecting the samples, they were washed with fresh water followed by distilled water to remove any associated epiphytes and debris. Then they were dried under shade for one week and in oven at $45{ }^{\circ} \mathrm{C}$ for $24 \mathrm{~h}$. The dried seaweeds were ground to powder with electric grinder mixer. 


\section{Preparation of seaweed extracts}

The crude seaweed extracts have been obtained using $n$-hexane, dichloromethane and $70 \%$ ethanol. The powdered sample of each species $(25 \mathrm{~g})$ was macerated in $n$-hexane $(200 \mathrm{ml})$ followed by dichloromethane $(200 \mathrm{ml})$ then $70 \%$ ethanol $(125 \mathrm{ml})$ at room temperature for one week with regular shaking. After filtration, solvents were evaporated under reduced pressure at $45^{\circ} \mathrm{C}$ to produce dry $n$ hexane (UFH1, UFH2, ULH and CSH), dichloromethane (UFM1, UFM2, ULM, COM, JRM and CSM) and ethanolic (UFE1, COE1, JRE1 and CSE1) extracts. The extraction procedure with each solvent was repeated once or twice again. The ethanolic extracts (UFE2, UFE3, ULE2, COE2 and JRE2) have been directly produced by maceration in $70 \%$ ethanol for 15 days. The obtained crude extracts were then kept at $-20^{\circ} \mathrm{C}$ until tested (Wefky et al., 2009; Shobier et al., 2010; Shobier et al., 2016).

\section{Test pathogenic bacteria}

The test microorganisms included Vibrio alginolyticus, V. parahaemolyticus, $V$. damsela, Vibrio sp. and A. hydrophila, were kindly obtained from Fish Diseases Department, Faculty of Veterinary Medicine, Alexandria University, Egypt.

\section{Antibacterial assay}

Antibacterial activity of the seaweed extracts against different pathogens was performed using well-cut diffusion technique (Hassan, 2016). Cephalexin (30 $\mu \mathrm{g})$, Rifampicin $(5 \mu \mathrm{g})$ and Piperacillin $(100 \mu \mathrm{g})$ were used as positive controls and DMSO was used as a negative control. After incubation at $37^{\circ} \mathrm{C}$ for $24 \mathrm{~h}$, the positive results were detected as clear zones around wells and measured in $\mathrm{mm}$.

\section{Activity index}

The activity index (AI) was used for comparing the antibacterial activity of each tested seaweed extract against all bacterial pathogens with that obtained from standard antibiotic.

$$
\mathrm{AI}=\frac{\text { Mean of the extract inhibition zone diameter }}{\text { Mean of the standard antibiotic drug inhibition zone diameter }}
$$

\section{Encapsulation and antibacterial activity of the most promising extracts}

The most promising seaweed extracts were separately mixed with sodium alginate solution $(2 \% \mathrm{w} / \mathrm{v})$ then dropped from a hydrodermic syringe to $100 \mathrm{ml}$ of (2\%) calcium chloride solution with constant stirring at $65^{\circ} \mathrm{C}$ and left to harden for 1 h. Finally the beads were washed with sterile distilled water and kept for use (Shobier et al., 2010). The antibacterial effect of the encapsulated extracts was estimated using shake-flask method (Ye et al., 2005). Briefly, predetermined amount of each formed encapsulated extract was inoculated into $50 \mathrm{ml}$ cell suspension of the tested pathogen with continuous shaking at $150 \mathrm{rpm}$ at rotary shaker. $1 \mathrm{ml}$ of sample solution was drawn and bacterial growth (optical density at $550 \mathrm{~nm}$ ) was detected and compared with that inoculated with free extract and free bacteria (Kim et al., 2007).

\section{Recycling of the encapsulated extract}

The reuse of the encapsulated extract was carried out by removing the medium and washing the beads after each cycle and then a new sterilized medium (50 $\mathrm{ml}$ ) was added, and new cycle was run. This process was repeated several times. At 
the end of each cycle the bacterial growth was estimated and expressed as optical density at $550 \mathrm{~nm}$ (Kim et al., 2007).

\section{Applications of the encapsulated extracts}

\section{Elimination of bacterial load in fish rearing water}

Certain volume of the encapsulated extracts of $C$. officinalis $(\mathrm{CA} / \mathrm{COM})$ and C. sinuosa (CA/CSE1) were separately amended in $50 \mathrm{ml}$ of fish rearing water, collected from El-Mex farm and incubated at $30{ }^{\circ} \mathrm{C}$ for $24 \mathrm{~h}$. One flask was kept as control (without addition of the encapsulated extracts). After that, estimation of total viable bacterial count and Vibrio spp. Counts was carried out and compared with control.

\section{Antifouling activity}

Antifouling activity was evaluated according to Kumaran et al. (2011). Briefly, seawater $(200 \mathrm{ml})$ was mixed separately with the encapsulated extracts of $C$. officinalis and $C$. sinuosa in a conical flask containing cover glass and incubated overnight at $30^{\circ} \mathrm{C}$ followed by dying with crystal violet solution $(0.4 \%)$ for 10 minutes, and washing with water, then drying at room temperature and checked under the microscope. One flask without extract was kept as control.

\section{Gas chromatography / Mass spectrometry (GC/MS) analysis}

GC/MS analysis was accomplished using GC instrument (Agilent 7890A) equipped with an HP-5MS column $(30 \mathrm{~m} \times 250 \mu \mathrm{m} \times 0.25 \mu \mathrm{m}$ film thickness $)$ and coupled with MS detector (Agilent 5975C). The initial oven temperature was programmed to be held at $90^{\circ} \mathrm{C}$ for $1 \mathrm{~min}$ then risen to $300^{\circ} \mathrm{C}$ for $30 \mathrm{~min}$ at a rate of $8^{\circ} \mathrm{C} / \mathrm{min}$. Helium was used as a carrier gas at a flow rate of $1.5 \mathrm{ml} / \mathrm{min}$. The injection volume of each sample was $1 \mu \mathrm{l}$ in the splitless mode where the injector temperature was $290^{\circ} \mathrm{C}$. Mass spectrum was operated at $70 \mathrm{ev}$ and mass range from 60-600 amu.

\section{Beads characterization}

The formed beads were coated with a layer of gold to examine their morphological and surface structure by scanning electron microscope (SEM) JEOL JSM-5300 at the required magnification and an acceleration voltage of $25 \mathrm{kV}$. Fourier transform infrared spectra (FTIR) were recorded on Bruker VERTEX 70 spectrometer in the range between 4000 and $400 \mathrm{~cm}^{-1}$ connected with platinum ART unit.

\section{Statistical analysis}

The experiments were performed in triplicate, and the results were recorded by the mean values and the standard deviations (SD). The experimental data were subjected to analysis of variance (one-way ANOVA) to determine significant differences where the term significant difference was referred to $p \leq 0.05$.

\section{RESULTS AND DISCUSSTION}

\section{Antibacterial activity of the seaweed extracts}

The present study concerned with screening for the antibacterial potential of different seaweed extracts against selected fish pathogens. Results revealed that the ethanolic extract of $C$. sinuosa (CSE1) exhibited the highest antibacterial activity 
showing average zone of inhibition $17.2 \mathrm{~mm}$ and activity index $1.4 \pm 0.74$ followed by the dichloromethane extract of $C$. officinalis (COM) with average zone of inhibition $14.4 \mathrm{~mm}$ and activity index $1.2 \pm 0.71$ (Table1 and Fig. 1). In accordance with the current study, Bansemir et al. (2006) studied the antibacterial potential of the components extracted from 26 algae species by methanol, water and dichloromethane against five fish pathogens and stated that the highest activities were recorded for the components extracted by dichloromethane due to the hydrophobic nature of some constituents, such as fatty products (Vatsos \& Rebours, 2015). On the other side, Redjem et al. (2013) reported that the extracts obtained by using polar solvents exhibited the highest antibacterial activity against the tested fish pathogens. Further, the yield of extractable materials and antimicrobials from different seaweed species depend on the solvent type. Antibacterial potential of algae against fish pathogens was reported in other studies (Rizzo et al., 2017; Saleh \& Al-Mariri, 2017). Natural factors, such as environmental conditions (climate, location, salinity, and temperature), pollution, the life stage, reproductive state, growth conditions, age of the seaweed as well as collection time and epiphytic organisms affect the chemical composition and antimicrobial activity of seaweeds revealing that this activity is not attributed to a single compound, but it could be related to some of them and to a combination of metabolites (Trigui et al., 2013; Stabili et al., 2014; Pérez et al., 2016).

Table 1: Diameter of the inhibition zones $(\mathrm{mm})$ of crude extracts against different fish pathogens

\begin{tabular}{|c|c|c|c|c|c|c|c|c|}
\hline \multirow[t]{2}{*}{ Species } & \multirow[t]{2}{*}{ Extract } & \multirow{2}{*}{$\begin{array}{l}\text { Sample } \\
\text { Code }\end{array}$} & \multicolumn{5}{|c|}{ Inhibition zone diameter $(\mathrm{mm})$} & \multirow[b]{2}{*}{ AVG } \\
\hline & & & $\begin{array}{c}\text { A. } \\
\text { hydrophila }\end{array}$ & $\begin{array}{l}\text { Vibrio } \\
\text { Sp. }\end{array}$ & $\begin{array}{c}V . \\
\text { parahaemolyticus }\end{array}$ & $\begin{array}{c}. \\
\text { alginolyticu }\end{array}$ & $\begin{array}{c}V . \\
\text { damsela }\end{array}$ & \\
\hline \multirow{4}{*}{$\begin{array}{c}\text { U. fasciata } \\
\text { (El-Manshia; } \\
\text { Jan. 2018) }\end{array}$} & Hexane & UFH1 & 0 & 10 & 12 & 16 & 0 & 7.6 \\
\hline & Dichloromethane & UFM1 & 0 & 11 & 0 & 0 & 0 & 2.2 \\
\hline & \multirow{2}{*}{ Ethanolic } & UFE1 & 0 & 0 & 0 & 0 & 0 & 0 \\
\hline & & UFE2 & 0 & 15 & 12 & 0 & 12 & 7.8 \\
\hline \multirow{3}{*}{$\begin{array}{l}\text { U. fasciata } \\
\text { (Abu Qir } \\
\text { Bay; Feb. } \\
\text { 2018) }\end{array}$} & Hexane & UFH2 & 0 & 0 & 0 & 0 & 0 & 0 \\
\hline & Dichloromethane & UFM2 & 0 & 0 & 0 & 0 & 0 & 0 \\
\hline & Ethanolic & UFE3 & 12 & 0 & 0 & 0 & 0 & 2.4 \\
\hline \multirow{3}{*}{$\begin{array}{c}\text { U. linza } \\
\text { (Abu Qir } \\
\text { Bay; Feb. } \\
\text { 2018) }\end{array}$} & Hexane & ULH & 0 & 0 & 0 & 0 & 0 & 0 \\
\hline & Dichloromethane & ULM & 0 & 0 & 0 & 0 & 0 & 0 \\
\hline & Ethanolic & ULE2 & 0 & 0 & 0 & 0 & 0 & 0 \\
\hline \multirow{3}{*}{$\begin{array}{l}\text { C. officinalis } \\
\text { (El-Manshia; } \\
\text { Jan. 2018) }\end{array}$} & Dichloromethane & $\mathrm{COM}$ & 17 & 15 & 20 & 20 & 0 & 14.4 \\
\hline & \multirow{2}{*}{ Ethanolic } & COE1 & 11 & 12 & 13 & 0 & 12 & 9.6 \\
\hline & & COE2 & 0 & 10 & 0 & 0 & 0 & 2 \\
\hline \multirow{3}{*}{$\begin{array}{c}\text { J. rubens } \\
\text { (Abu Qir } \\
\text { Bay; Feb. } \\
2018 \text { ) }\end{array}$} & Dichloromethane & JRM & 0 & 17 & 16 & 0 & 0 & 6.6 \\
\hline & \multirow{2}{*}{ Ethanolic } & JRE1 & 0 & 0 & 0 & 0 & 0 & 0 \\
\hline & & JRE2 & 0 & 12 & 13 & 18 & 0 & 8.6 \\
\hline \multirow{3}{*}{$\begin{array}{l}\text { C. sinuosa } \\
\text { (Abu Qir } \\
\text { Bay; Feb. } \\
\text { 2018) }\end{array}$} & Hexane & $\mathrm{CSH}$ & 11 & 12 & 15 & 11 & 0 & 9.8 \\
\hline & Dichloromethane & CSM & 0 & 0 & 0 & 0 & 0 & 0 \\
\hline & Ethanolic & CSE1 & 15 & 18 & 19 & 19 & 15 & 17.2 \\
\hline Piperacillin & $(100 \mu \mathrm{g})$ & & 20 & 14 & 18 & 0 & 8 & 12 \\
\hline Rifampicin & $(5 \mu \mathrm{g})$ & & 12 & 0 & 15 & 0 & 10 & 7.4 \\
\hline Cephalexin & $(30 \mu \mathrm{g})$ & & 0 & 0 & 33 & 0 & 0 & 6.6 \\
\hline
\end{tabular}




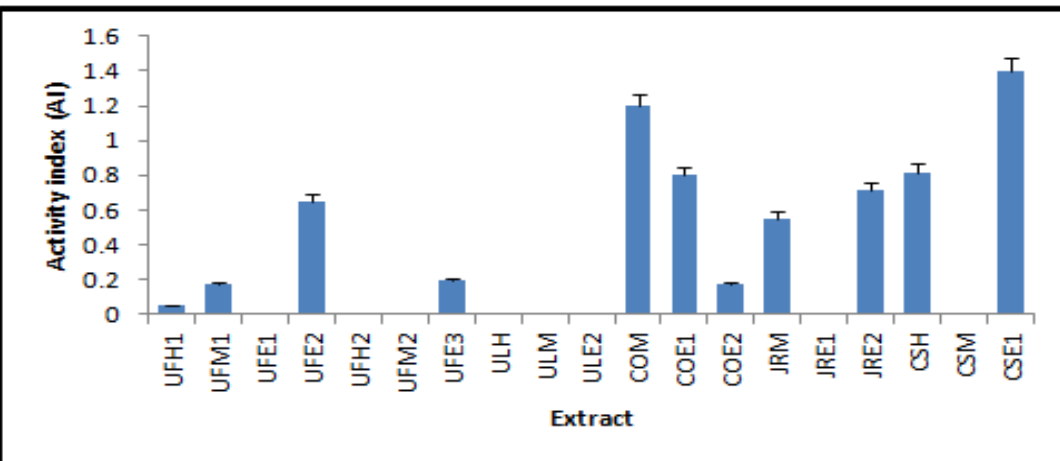

Fig. 1: Activity index of the crude seaweed extracts against the tested bacterial pathogens. Bars are expressed as mean $\pm \mathrm{SE}$.

\section{Antibacterial activity of the encapsulated extracts (CA/COM) and (CA/CSE1)}

The most effective extracts in term of antibacterial activity were selected and encapsulated into calcium alginate beads, to be further investigated against the most sensitive bacterial pathogens. Antibacterial activity of the encapsulated C. officinalis dichloromethane extract $(\mathrm{CA} / \mathrm{COM})$ was tested against $V$. parahaemolyticus, $V$. alginolyticus and $A$. hydrophila, while the encapsulated ethanolic extract of $C$. sinuosa (CA/CSE1) was tested against $V$. parahaemolyticus, $V$. alginolyticus and Vibrio sp. using shake flask method. Results (Fig. 2 A) indicated that the highest significant $(P=0.031)$ bacterial inhibition caused by $(\mathrm{CA} / \mathrm{COM})$ extract against $V$. parahaemolyticus was after $5 \mathrm{~min}$, where the bacterial growth $\left(\mathrm{OD}_{550}\right)$ reached $95 \times 10^{-3}$ recording 2 fold decrease in the bacterial growth compared with free bacteria $\left(190 \times 10^{-3}\right)$ at the same time and the effect was prolonged up to $35 \mathrm{~min}$, followed by an increase in the bacterial growth, however still more active than the free extract. Similar behavior was observed against $V$. alginolyticus and A. hydrophila (Fig. 2 B, $\mathrm{C})$, where the bacterial reduction started 5 min post addition of the encapsulated extract (CA/COM) with 1.8 and 1.6 fold decrease in the bacterial growth, respectively compared with free bacteria at the same time.

Regarding the effect of $C$. sinuosa ethanolic extract (CA/CSE1) on the growth of the tested pathogens, elimination of $V$. parahaemolyticus and Vibrio sp. was significant $(P=0.013$ and 0.042$)$ and observed after 5 min with 1.4 and 1.3 fold decrease in growth, respectively compared with the growth of free bacteria after 5 min (Fig. 2 D, F). Delayed effect against $V$. alginolyticus was observed to be after 10 min post beads addition, recording 1.6 fold decrease in the bacterial growth compared with growth of free bacteria (Fig. 2E). The encapsulated beads (CA/CSE1) exhibited conservative effect against Vibrio sp. during 10-30 min, followed by slight decrease at $35 \mathrm{~min}$. Overall results concluded that the encapsulation of $C$. sinuosa and $C$. officinalis extracts revealed better significant antibacterial effect (significant at $\mathrm{P}<0.05)$ compared with the free extract during the period of study. This effect may be attributed to the hydrophobicity of the calcium alginate beads entrapping the extract, which provides protection of the bioactive metabolites, controlled release of the bioactive components and allowing more surface contact (Millette et al., 2007). In a previous study by Shobier et al. (2010), the encapsulated methanolic extract of Pterocladia capillacea showed good antibacterial activity against Aeromonas hydrophila, Pseudomonas fluorescens and Vibrio anguillarum. 

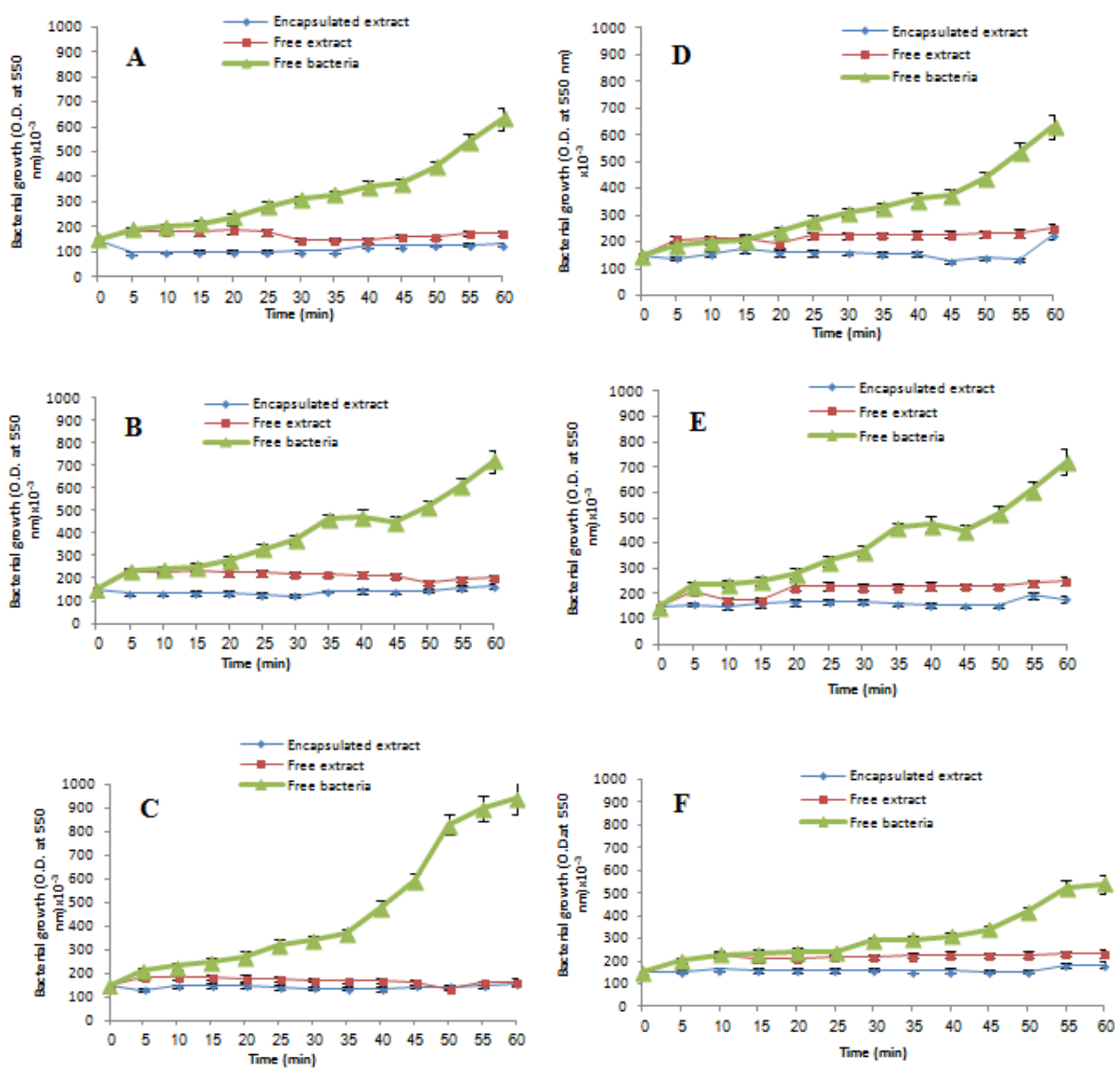

Fig. 2: Antibacterial activity of free and encapsulated extracts of $C$. officinalis against (A) $V$. parahaemolyticus, (B) V. alginolyticus, (C) A. hydrophila and of free and encapsulated extracts of C. sinuosa against (D) V. parahaemolyticus, (E) V. alginolyticus and (F) Vibrio sp.

\section{Recycling of the most active extracts}

The effective entrapped dichloromethane extract of C. officinalis (CA/COM) was recycled for 7 successive cycles. As shown in Fig. 3, the reduction of bacterial growth started at the first cycle and prolonged till the third cycle, followed by lower reduction in the bacterial growth, however still lower than the control (uninoculated with encapsulated beads). Our study was supported by study of Kim et al. (2007) who reported the potential inactivation of bacterial pathogens for successive cycles.

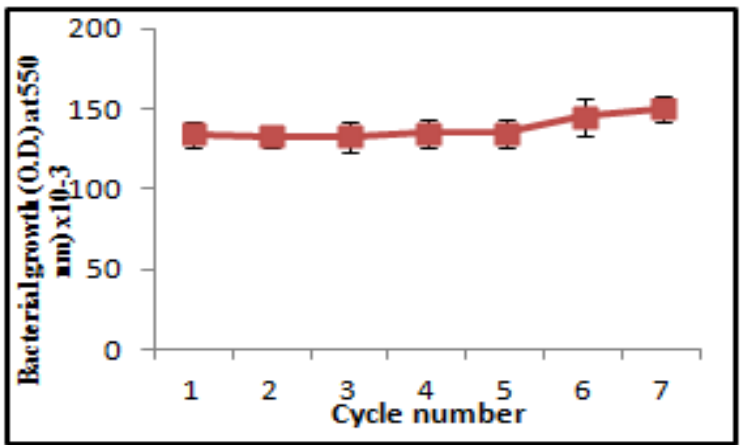

Fig. 3: Recycling of the encapsulated dichloromethane extract of $C$. officinalis (CA/COM). 
Applications of the encapsulated extracts Efficiency of the encapsulated extracts in elimination of bacterial load in fish rearing water

Infection with Vibrio is one of the most abundant and devastating diseases in aquaculture. Some Vibrio strains including $V$. splendidus, $V$. harveyi and $V$. parahaemolyticus are resistant to different antibiotics. Thus, there is a must to innovative eco-friendly alternatives. So the aim of the present experiment was a trial to eliminate the Vibrio load in fish rearing water collected from El-Mex fish farm. A determined volume of the encapsulated extracts was added to $50 \mathrm{ml}$ of the fish rearing water and then estimation of Vibrio spp. and total bacterial counts (TVC) was carried out after $24 \mathrm{~h}$. Results shown in Fig. 4 revealed the elimination of Vibrio spp. with $93.7 \%$ and $90 \%$ after addition of the encapsulated extract of $C$. officinalis (CA/COM) and C. sinuosa (CA/CSE1), respectively. On the other hand TVC was also reduced by $90 \%$ compared with the control (without addition of the encapsulated extract). Oliveira et al. (2014) stated that addition of the brown algae Ascophyllum nodosum as meals to the diet of Nile tilapia infected with $A$. hydrophila enhanced the sanitary status of the fish and occurrence of the infection was lower. Previous studies reported in vivo antibacterial activity of water, methanol and dichloromethane extracts of different algal species against Vibrio anguillarum, Aeromonas salmonicida, Pseudomonas anguilliseptica, A. hydrophila, Yersinia ruckeri, and shrimp Vibrio pathogens for aquaculture sanitary (Bansemir et al., 2006, Manilal et al., 2012; Rizzo et al., 2017; Wan et al., 2018).

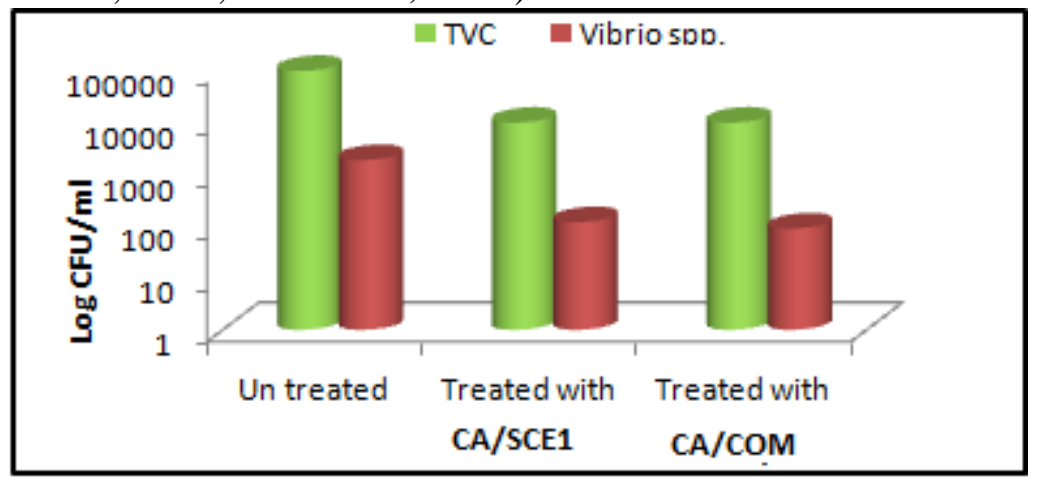

Fig. 4: Counts of total bacteria (TVC) and Vibrio spp. before and after treatment with the encapsulated extracts of $C$. officinalis and C. sinuosa.

\section{Antifouling activity of the encapsulated extracts}

Marine biofouling is a paramount phenomenon in the marine environment, which leads to serious problems to marine industries worldwide (Saha et al., 2017). The present experiment focused on the antagonistic effect of the encapsulated extracts of $C$. officinalis and $C$. sinuosa on biofilm formation. Fig. 5 A, B show the reduction of the bacterial load in the formed biofilm by the action of $C$. sinuosa and C. officinalis encapsulated extracts compared with the control (biofilm formed without addition of the encapsulated extract) (Fig. 5 C). This confirmed the potential antifouling activity of both encapsulated extracts. In accordance with the obtained results, Bazes et al. (2006) reported the antifouling activity of the marine alga Ceramium botryocarpum extracts against Vibrio sp. and Pseudovibrio denitrificans which are associated with immersed surfaces. The aqueous, ethanolic and dichloromethane extracts of 30 marine algae exhibited high levels of in vitro antifouling activity against 35 isolates of marine bacteria (Hellio et al., 2001; Pérez et al., 2016). Another report showed that the addition of algal extract to paint enhances the quality for 6 weeks (Chambers et al., 2011). 




Fig. 5: Photographs illustrating the antifouling effect of the encapsulated extract of (A) C. sinuosa, (B) C. officinalis and (C) control (uninoculated).

\section{GC/MS analysis of the most potential extracts (COM and CSE1)}

The identification of the unknown phytochemicals of the $C$. officinalis and $C$. sinuosa crude extracts was confirmed by comparison of their mass spectra with those of standard compounds stored in the NIST library.

\section{GC/MS analysis of the $C$. officinalis dichloromethane extract (COM)}

The GC/MS chromatogram of the dichloromethane extract of $C$. officinalis harvested from El-Manshia exhibited 17 peaks (Fig. 6) of which 12 peaks were identified. The chemical compositions of the dichloromethane extract are shown in Table 2. The most abundant six constituents were $n$-nonadecane ( $\mathrm{RT}=16.95 \mathrm{~min}$ ), 1,2,3-propanetricarboxylic acid, 2-(acetyloxy)-, tributyl ester ( $\mathrm{RT}=27.18 \mathrm{~min}), 2$ methylhexadecan-1-ol $(\mathrm{RT}=22.18 \mathrm{~min}), 1$-docosene $(\mathrm{RT}=25.89 \mathrm{~min}), 1$-eicosanol $(\mathrm{RT}=29.20 \mathrm{~min})$ and chloroacetic acid, octadecyl ester $(\mathrm{RT}=18.58 \mathrm{~min})$. Ismail (2017) reported that $C$. officinalis contains high content of carotenoid $(3.8 \mathrm{mg} / \mathrm{g}$ dry wt.), $\beta$-Carotene (3940.12 IU/100 g) and carbohydrates (27.98\% of dry wt.). Moreover, C. officinalis exhibited good antioxidant activity (72.6\%). Borik (2014) found that the volatile constituents of this alga consist of monoterpenes (1.17\%), diterpenes $(0.07 \%)$, aldehydes $(1.42 \%)$, ketones $(0.72 \%)$, alcohols $(0.17 \%)$, esters $(15.30 \%)$, aliphatic hydrocarbons $(38.88 \%)$, cyclic hydrocarbons $(0.35 \%)$, phenol $(2.87 \%)$, heterocyclic $(0.19 \%)$ and miscellaneous $(0.87 \%)$. Djapic (2018) identified and quantified the chemical constituents of $C$. officinalis and indicated that the alga contains $8.42 \%$ monoterpenes, $2.02 \%$ sesquiterpenes, $4.32 \%$ diterpenes, $13.64 \%$ triterpenes, $14.92 \%$ acyclic alkanes, $2.06 \%$ branched alkanes, $5.44 \%$ alkenes, $0.6 \%$ aromatic compound, $2.88 \%$ organobromine and $0.6 \%$ organosulfur compounds. The triterpene squalene was the most predominant compound which was found in a percentage of $13.64 \%$.

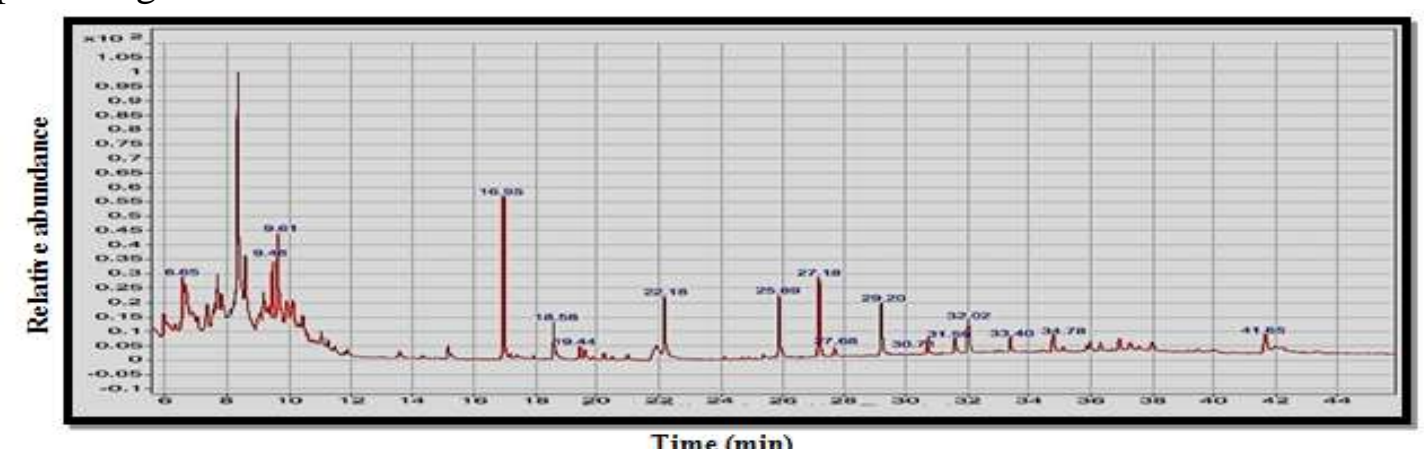

Fig. 6: GC/MS chromatogram of the dichloromethane extract of C. officinalis (COM). 
Table 2: Chemical constituents and biological activity of $C$. officinalis dichloromethane extract (COM)

\begin{tabular}{|c|c|c|c|c|c|c|c|}
\hline $\begin{array}{c}\text { Peak } \\
\text { no. }\end{array}$ & $\begin{array}{l}\mathrm{RT} \\
(\mathrm{min})\end{array}$ & Component name & $\begin{array}{l}\text { Molecular } \\
\text { formula }\end{array}$ & $\begin{array}{l}\text { MW } \\
(\mathrm{m} / \mathrm{z})\end{array}$ & Chemical structure & Biological activity & Reference \\
\hline 1 & 6.65 & Unidentified & - & - & - & - & - \\
\hline 2 & 9.48 & Unidentified & - & - & - & - & - \\
\hline 3 & 9.61 & Unidentified & - & - & - & - & - \\
\hline 4 & 16.95 & $n$-Nonadecane & $\mathrm{C}_{19} \mathrm{H}_{40}$ & 268 & & Cytotoxic, antimicrobial & Hsouna et al. (2011) \\
\hline 5 & 18.58 & $\begin{array}{l}\text { Chloroacetic acid, } \\
\text { octadecyl ester }\end{array}$ & $\mathrm{C}_{20} \mathrm{H}_{39} \mathrm{ClO}_{2}$ & 346 & & ------- & ------- \\
\hline 6 & 19.44 & $\begin{array}{l}\text { Cholestan-3-ol, 2- } \\
\text { methylene-, }(3 \beta, 5 \alpha)\end{array}$ & $\mathrm{C}_{28} \mathrm{H}_{48} \mathrm{O}$ & 400 & & Anti-inflammatory & Al-Rubaye et al. (2017) \\
\hline 7 & 22.18 & $\begin{array}{l}\text { 2-Methylhexadecan-1- } \\
\text { ol }\end{array}$ & $\mathrm{C}_{17} \mathrm{H}_{36} \mathrm{O}$ & 256 & & ------- & ------- \\
\hline 8 & 25.89 & 1-Docosene & $\mathrm{C}_{22} \mathrm{H}_{44}$ & 308 & & Antibacterial & Beevi et al. (2014) \\
\hline 9 & 27.18 & $\begin{array}{c}1,2,3- \\
\text { Propanetricarboxylic } \\
\text { acid, 2-(acetyloxy)-, } \\
\text { tributyl ester }\end{array}$ & $\mathrm{C}_{20} \mathrm{H}_{34} \mathrm{O}_{8}$ & 402 & & Antibacterial & Al-Rubaye et al. (2017) \\
\hline 10 & 27.68 & $\begin{array}{c}\text { 1,1-Dimethyltetradecyl } \\
\text { hydrosulfide }\end{array}$ & $\mathrm{C}_{16} \mathrm{H}_{34} \mathrm{~S}$ & 258 & & Antioxidant, antibacterial & Sivakumar (2014) \\
\hline
\end{tabular}




\begin{tabular}{|c|c|c|c|c|c|c|c|}
\hline 11 & 29.20 & 1-Eicosanol & $\mathrm{C}_{20} \mathrm{H}_{42} \mathrm{O}$ & 298 & $\sim r$ & Anticancer, antimicrobial & $\begin{array}{l}\text { Wong \& Kadir (2011); } \\
\text { Karthi et al. (2015) }\end{array}$ \\
\hline 12 & 30.71 & $\begin{array}{c}1,54- \\
\text { Dibromotetrapenta- } \\
\text { contane }\end{array}$ & $\mathrm{C}_{54} \mathrm{H}_{108} \mathrm{Br}_{2}$ & 914 & & ------- & ------- \\
\hline 13 & 31.59 & $\begin{array}{c}\text { 3',8,8'-Trimethoxy-3- } \\
\text { piperidin-1-yl-2,2'- } \\
\text { binaphthyl-1,1',4,4'- } \\
\text { tetrone }\end{array}$ & $\mathrm{C}_{28} \mathrm{H}_{25} \mathrm{NO}_{7}$ & 487 & & Antioxidant & $\begin{array}{c}\text { Nazareth \& Vijayalakshmi } \\
\text { (2014) }\end{array}$ \\
\hline 14 & 32.02 & $\begin{array}{c}(17 E)-17- \\
\text { Pentatriacontene }\end{array}$ & $\mathrm{C}_{35} \mathrm{H}_{70}$ & 490 & & Antibacterial, antiviral & $\begin{array}{l}\text { Paramanantham \& } \\
\text { Murugesan (2014) }\end{array}$ \\
\hline 15 & 33.40 & 2-Octadecoxyethanol & $\mathrm{C}_{20} \mathrm{H}_{42} \mathrm{O}_{2}$ & 314 & & Antimicrobial & Karthi et al. (2015) \\
\hline 16 & 34.78 & Unidentified & - & - & - & - & - \\
\hline 17 & 41.65 & Unidentified & - & - & - & - & - \\
\hline
\end{tabular}




\section{GC/MS analysis of the $C$. sinuosa ethanolic extract (CSE1)}

The chemical constituents identified by GC-MS analysis of the ethanolic extract of $C$. sinuosa collected from Abu Qir Bay presented in Fig. 7 and Table 3. $n$ Tridecanoic acid ethyl ester $(\mathrm{RT}=22.38 \mathrm{~min}$ ) was found as the major component followed by tetradecanoic acid, ethyl ester $(\mathrm{RT}=18.66 \mathrm{~min}), n$-hexadecanoic acid $(\mathrm{RT}=22.03 \mathrm{~min})$, ethyl $(9 Z, 11 E)-9,11$-octadecadienoate $(\mathrm{RT}=29.02 \mathrm{~min})$, ethyl $n$ heptadecanoate $(\mathrm{RT}=29.28 \mathrm{~min})$, bis (2-ethylhexyl) 1,2-benzenedicarboxylate $(\mathrm{RT}=$ $31.61 \mathrm{~min}), 6,10,14$-trimethylpentadecan-2-one $(\mathrm{RT}=19.64 \mathrm{~min})$ and $n$-pentadecanoic acid ethyl ester $(\mathrm{RT}=25.96 \mathrm{~min}$ ) (Table 3). El-Shora et al. (2018) isolated the polysaccharide fucoidan from $C$. sinuosa which possessed appreciable antibacterial activity. Pasdaran et al. (2016) reported that the volatile oil of $C$. sinuosa contains 2iodo-3-methyl-butane, 2-undecanone, 1-dodecanol, 2-tridecene, tridecane, neryl acetone, edulan I, pseudoionone, 1-tridecanol, 1-tetradecene, 1-tetradecanol, pentadecane, 7-pentadecanone, hexadecane, 1-hexadecanol and 8-heptadecene, 1chloro.It was found that hexadecane and 7-pentadecanone are the main components of the volatile oil. However, a significant antibacterial activity was not observed.



Fig. 7: GC/MS chromatogram of the ethanolic extract of $C$. sinuosa (CSE1). 
Table 3: Chemical constituents of and biological activity of $C$. sinuosa ethanolic extract (CSE1)

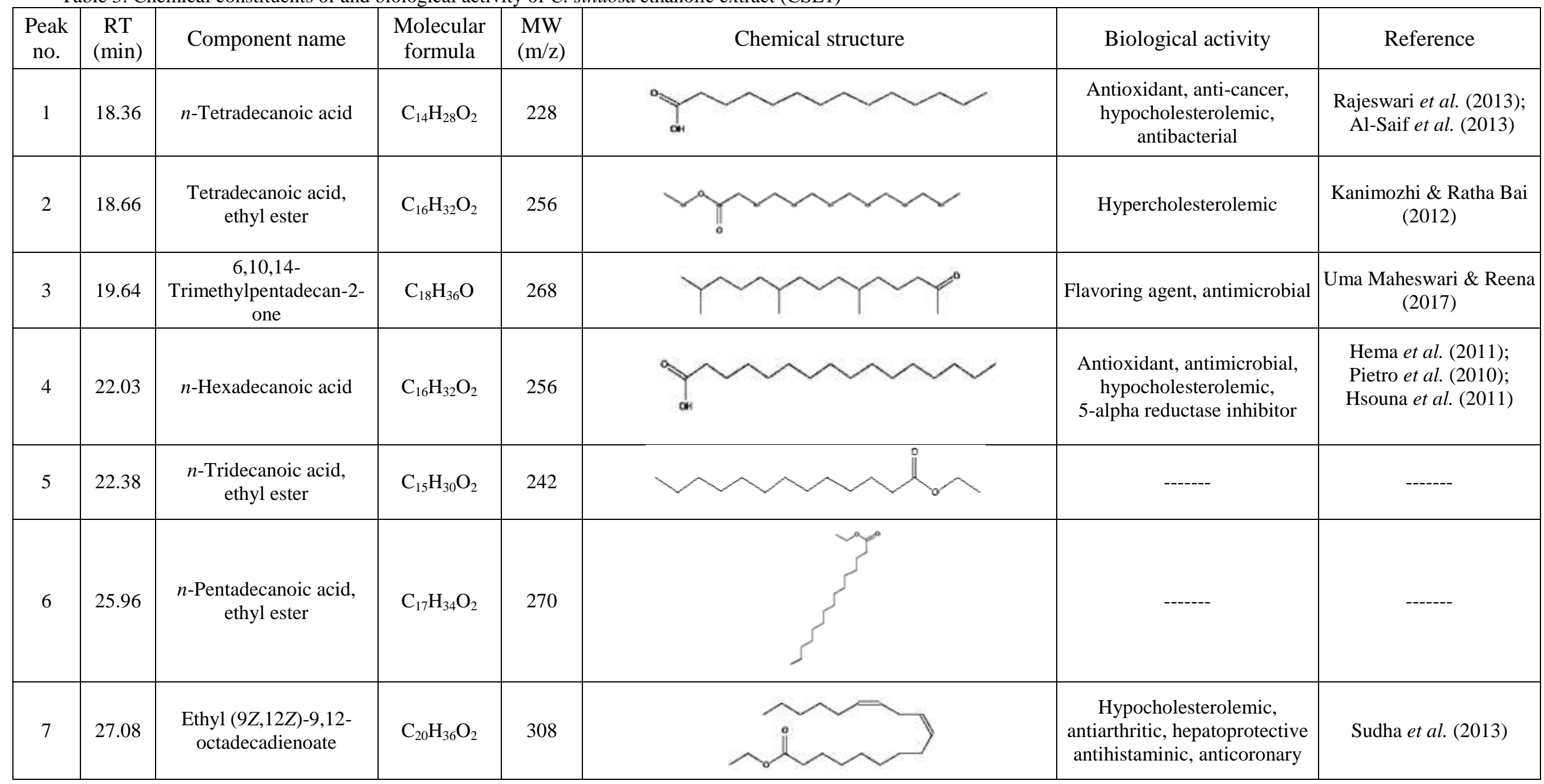




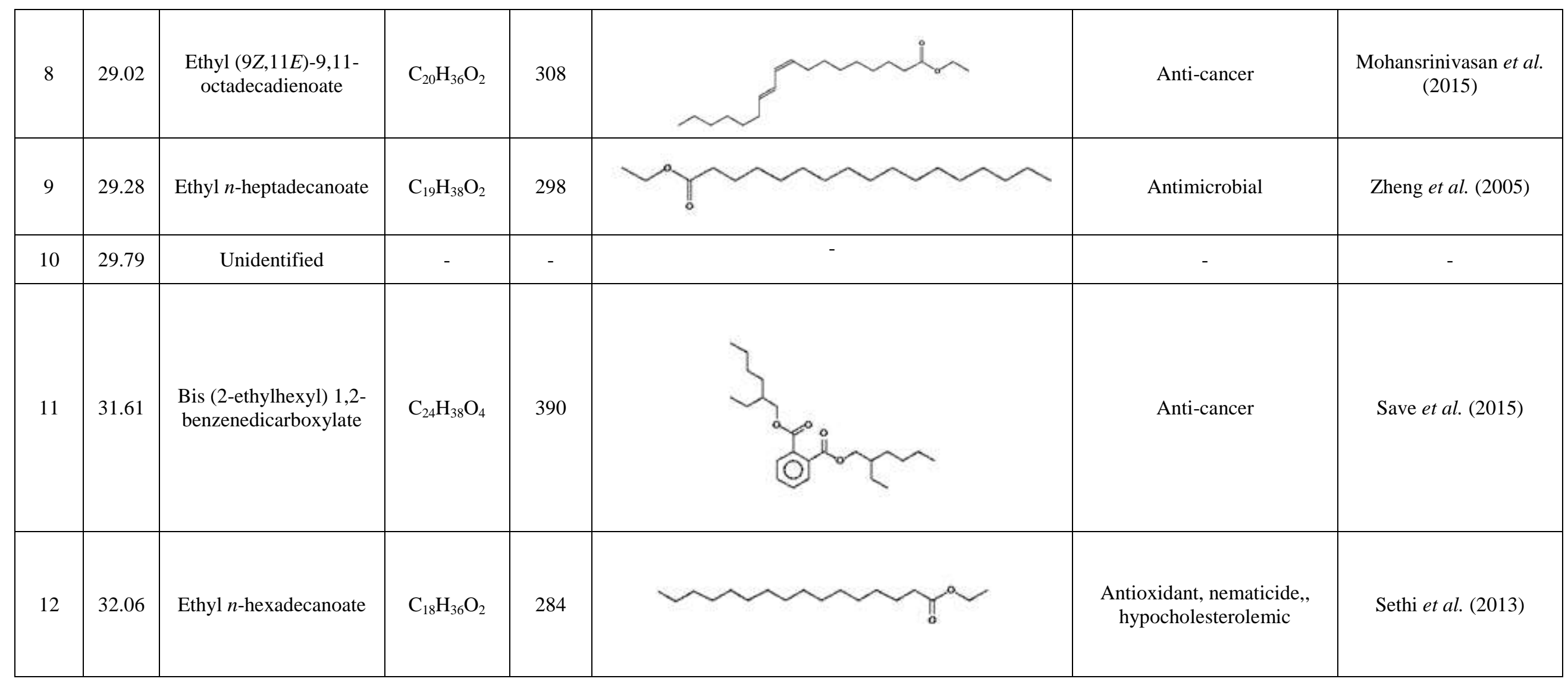




\section{Characterization of alginate beads Scanning electron microscopic study}

The beads were analyzed by scanning electron microscope to evaluate the morphology and the bead surface. SEM photographs of the outer surface of plain and encapsulated beads (CA, CA/COM and CA/CSE1, respectively) appear flattened, rough and very irregular with a porous structure which appears like that of an orange peel (Fig. 8 A, B, C). The drying of the beads had big effect on their morphology and texture which leads to the deformation of the surface. SEM images of the inner surface show that the beads have porous nature with a sponge like structure in which the extracts were entrapped (Fig. 9 A, B, C).
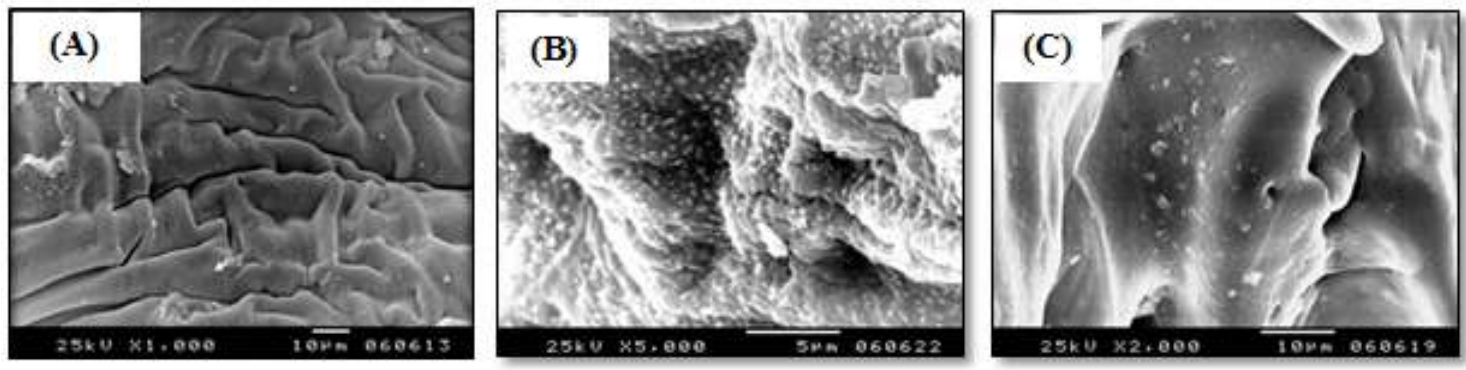

Fig. 8: SEM of the outer surface of (A) plain Ca-alginate beads (CA), (B) Ca-alginate beads encapsulated with $C$. officinalis extract $(\mathrm{CA} / \mathrm{COM})$ and $(\mathrm{C}) \mathrm{Ca}$-alginate beads encapsulated with $C$. sinuosa extract (CA/CSE1).
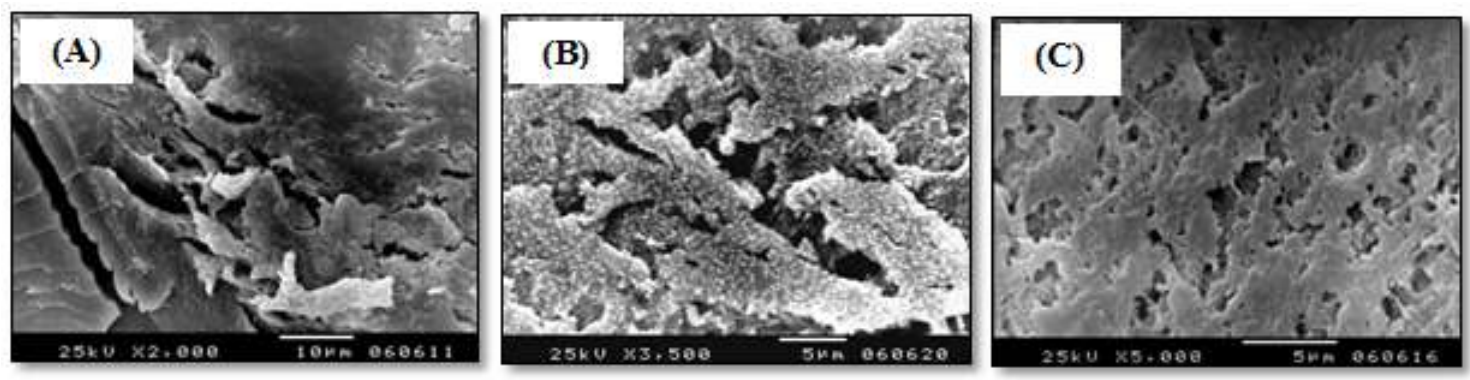

Fig. 9: SEM of the inner surface of (A) plain Ca-alginate beads (CA), (B) Ca-alginate beads encapsulated with $C$. officinalis extract $(\mathrm{CA} / \mathrm{COM})$ and $(\mathrm{C}) \mathrm{Ca}$-alginate beads encapsulated with $C$. sinuosa extract (CA/CSE1).

\section{FTIR study}

The FTIR spectrum of plain beads (CA) shows a broad band at $\left(3266 \mathrm{~cm}^{-1}\right)$ attributed to $\mathrm{O}-\mathrm{H}$ stretching. The band around $\left(2926 \mathrm{~cm}^{-1}\right)$ could be related to aliphatic C-H vibration. The two peaks around $\left(1600\right.$ and $\left.1418 \mathrm{~cm}^{-1}\right)$ are assigned to carboxylate $-\mathrm{COO}^{-}$asymmetric/symmetric stretching. The bands at (1078 and 1021 $\mathrm{cm}^{-1}$ ) are assigned to the $-\mathrm{C}-\mathrm{O}$ stretching of ether and alcoholic groups, respectively (Fig. $10 \mathrm{~A}$ ). The spectrum of alginate beads encapsulated with $C$. officinalis dichloromethane extract (CA/COM) (Fig. $10 \mathrm{~B}$ ) shows stretching frequencies of $\mathrm{O}-\mathrm{H}$ groups $\left(3279 \mathrm{~cm}^{-1}\right),-\mathrm{COO}^{-}$asymmetric/symmetric stretching $\left(1603\right.$ and $\left.1415 \mathrm{~cm}^{-1}\right)$, $-\mathrm{C}-\mathrm{O}$ stretching of the ether group $\left(1080 \mathrm{~cm}^{-1}\right)$ of alginate and -C-O stretching band attributed to alcoholic group $\left(1024 \mathrm{~cm}^{-1}\right)$. The FTIR spectrum of alginate beads encapsulated with $C$. sinuosa ethanolic extract (CA/CSE1) indicated that the position of the O-H stretching band is shifted to $\left(3340 \mathrm{~cm}^{-1}\right)$. Other peaks appeared at 1600 , 1423, 1080 and $1021 \mathrm{~cm}^{-1}$, respectively (Fig. $10 \mathrm{C}$ ). These spectra revealed that all characteristic functional groups originally exist on the plain alginate beads are still 
present after encapsulation except the two bands at $\left(2322\right.$ and $\left.2284 \mathrm{~cm}^{-1}\right)$ disappeared in the encapsulated beads.



Fig. 10: FTIR spectra of (A) plain Ca-alginate beads (CA), (B) Ca-alginate beads encapsulated with $C$. officinalis extract (CA/COM) and (C) Ca-alginate beads encapsulated with $C$. sinuosa extract (CA/CSE1).

\section{CONCLUSIONS}

The investigated extracts of $C$. officinalis and $C$. sinuosa were found to contain some phytocomponents such as 1-docosene, 1,2,3-propanetricarboxylic acid, 2(acetyloxy)- tributyl ester, 1,1-dimethyltetradecyl hydrosulfide, 1-eicosanol, (17E)17-pentatriacontene, 2-octadecoxyethanol, $n$-tetradecanoic acid, $n$-hexadecanoic acid, ethyl $n$-heptadecanoate and 6,10,14-trimethylpentadecan-2-one possessing a widespectrum of antimicrobial activity. So these seaweeds may be used as a natural antibacterial agent for fish pathogenic bacteria. In order to control fish infection, these seaweed extracts could be further investigated as dietary supplements of farmed fish, in a modern and eco-sustainable aquaculture. The present study encourages the use of the encapsulated extract as biocontrol agent in the aquaculture.

\section{ACKNOWLEDGMENTS}

This work was financially supported by National Institute of Oceanography and Fisheries (NIOF), Egypt, project number (Env. D-13-2017). The authors are grateful to Prof. Dr. Nihal G. Shams El-Din and Dr. Mona M. Ismail, Division of Marine Environment, National Institute of Oceanography and Fisheries for identifying the investigated seaweeds.

\section{REFERENCES}

Aleem, A.A. (1993). The marine algae of Alexandria. Egyptian Books House, Egypt.

Al-Rubaye, A.F.; Kaizal, A.F. and Hameed, I.H. (2017). Phytochemical screening of methanolic leaves extract of Malva sylvestris. Int. J. Pharmacognosy Phytochem. Res., 9 (4): 537-552.

Al-Saif, S.S.; Abdel-Raouf, N.; El-Waznani, H.A. and Aref, I.A. (2013). Antibacterial substances from marine algae isolated from Jeddah coast of Red Sea. Saudi Arabia J. Biol. Sci., 18: 2328-2357.

Azzi, J. ; Danjou, P.E.; Landy, D.; Ruellan, S.; Auezova, L.; Greige-Gerges, H. and Fourmentin, S. (2017). The effect of cyclodextrin complexation on the solubility and photostability of nerolidol as pure compound and as main constituent of cabreuva essential oil. Beilstein J. Org. Chem., 13: 835-844. 
Bansemir, A.; Blume, M.; Schroder S. and Lindequist U. (2006). Screening of cultivated seaweeds for antibacterial activity againstfish pathogenic bacteria. Aquaculture, 252: 79-84.

Bazes, S.; Silkina, A.; Defer, D.; Bernède-Bauduin, C.; Quéméner, E.; Braud, J.P. and Bourgougnon, N. (2006). Active substances from Ceramium botryocarpum used as antifouling products in aquaculture. Aquaculture, 258: 664-674.

Beevi, A.H.; Maruthupandy, M.; Priya, R.J. and Anand, M. (2014). Characterization of metabolites of Bacillus subtilis isolated from sea surface microlayer and its antibacterial activity. Int. J. Pharm Sci. Health Care, 2 (4): 15-24.

Bondad-Reantaso, M.G.; Subasinghe, R.P.; Arthur, J.R.; Ogawa, K.; Chinabut, S.; Adlard, R.; Tan, Z. and Shariff, M. (2005). Disease and health management in Asian aquaculture.Vet. Parasitol., 132: 249-272.

Borik, R.M. (2014). Volatile compounds extraction, fractionation and identification from the red alga Corallina officinalis. WASJ, 30 (6): 741-746.

Chakraborty, S.; Ghosh, U.; Balasubramanian, T. and Das, P. (2014). Screening, isolation and optimization of anti-white spot syndrome virus drug derived from marine plants. Asian Pac. J. Trop. Biomed., (4): S107-S117.

Chambers, L.D.; Hellio, C.; Stokes, K.R.; Dennington, S.P.; Goodes, L.R.; Wood, R.J.K. and Walsh, F.C. (2011). Investigation of Chondrus crispus as a potential source of new antifouling agents. Int. Biodeterior. Biodegrad., 65: 939-946.

Clare, A.S. (1996). Marine natural product antifoulants: status and potential. Biofouling, 9: 211-229.

Cruz-Suárez, L.E.; Tapia-Salazar, M.; Nieto-López, M.G. and Ricque-Merie, D. (2008). A review of the effects of macroalgae in shrimp feeds and in co-culture. In: Cruz-Suárez, L.E., Tapia-Salazar, M., Nieto-López, M.G. (Eds.), Avances en Nutrición Acuícola IX. UANL, Monterrey, pp. 304-333.

Djapic, N. (2018). Corallina officinalis chemical compounds obtained by supercritical fluid extraction. AACL Bioflux, 11(2): 422-428.

Dobretsov, S.; Al-Wahaibi, A.S.M.; Lai, D.; Al-Sabahi, J.; Claereboudt, M.; Proksch, P. and Soussi, B. (2015). Inhibition of bacterial fouling by soft coral natural products. Int. Biodeterior. Biodegradation, 98: 53-58.

El-Shora, H.M.; Abou-El-Wafa, G.S. and Abu-Eftouh, N.M. (2018). Fucoidan and fucoidanase from brown seaweeds and applications. Int. J. Curr. Microbiol. App. Sci., 7(2): 3707-3715.

Ephrem, E.; Najjar, A.; Charcosset, C. and Greige-Gerges H. (2018). Encapsulation of natural active compounds, enzymes, and probiotics for fruit juice fortification, preservation, and processing: An overview. J. Funct. Foods, 48: $65-84$.

FAO (2016). The State of World Fisheries and Aquaculture 2016. Contributing to food security and nutrition for all, Rome (200 pp.).

Fernando, I.P.S.; Sanjeewa, K.K.A.; Kim, S.-Y.; Lee, J.-S. and Jeon, Y.-J. (2018). Reduction of heavy metal $\left(\mathrm{Pb}^{2+}\right)$ biosorption in zebrafish model using alginic acid purified from Ecklonia cava and two of its synthetic derivatives. Int. J. Biol. Macromol., 106: 330-337.

Fleurence, J.; Morançais, M.; Dumay, J.; Decottignies, P.; Turpin, V.; Munier, M.; GarciaBueno, N. and Jaouen, P. (2012). What are the prospects for using seaweed in human nutrition and for marine animals raised through aquaculture? Trends Food Sci. Technol., 27: 57-61. 
Gharib, R.; Auezova, L.; Charcosset, C. and Greige-Gerges, H. (2017). Drug-incyclodextrinin-liposomes as a carrier system for volatile essential oil components: Application to anethole. Food Chem., 218: 365-371.

Goyal, S.; Gupta, N.; Chatterjee, S. and Nimesh, S. (2017). Natural plant extracts as potential therapeutic agents for the treatment of cancer. Curr. Top. Med. Chem., 17: 96-106.

Hassan, S.W. (2016). Antibacterial, anticoagulant and anti-inflammatory activities of marine Bacillus cereus S1. J. Pure. Appl. Microbiol., 10(4): 2593-2606.

Hellio, C.; De La Broise, D.; Dufossé, L.; Le Gal, Y. and Bourgougnon, N. (2001). Inhibition of marine bacteria by extract of macroalgae: Potential use for environmentally friendly paints. Mar. Environ. Res., 52: 231-247.

Hema, R.; Kumaravel, S. and Alagusundaram, K. (2011). GC/MS Determination of bioactive components of Murraya koenigii. J. Am. Sci., 7 (1): 80-83.

Hsouna, A.B.; Trigie, M.; Mansour, R.B.; Jarraya, R.M.; Damak, M. and Jaoua, S. (2011). Chemical composition, cytotoxicity effect and antimicrobial activity of Ceratonia silisqua essential oil with preservative effects against listeria inoculated in minced beef meat. Int. J. Food, 148(1): 66-72.

Ismail, G.A. (2017). Biochemical composition of some Egyptian seaweeds with potent nutritive and antioxidant properties. Food Sci. Technol. Campinas, 37(2): 294-302.

Kanimozhi, D. and Ratha Bai, V. (2012). Analysis of bioactive components of ethanolic extract of Coriandrum Sativum L. Int. J. Res. Pharm. Sci., 2(3), 97110.

Karthi, S.; Somanath, B. and Abdul Jaffar A.H. (2015). Efficacy of methanolic extract of a marine ascidian, Lissoclinum bistratum for antimicrobial activity. J. Chem. Bio. Phy. Sci. Sec. B, 5 (4): 4119-4125.

Kavoosi, G.; Derakhshan, M.; Salehi, M. and Rahmati, L. (2018). Microencapsulation of zataria essential oil in agar, alginate and carrageenan. Innov. Food Sci. Emerg. Technol., 45: 418-425.

Kim, Y.S.; Kim, H.W.; Lee, S.H.; Shin, K.S.; Hur, H.W. and Rhee, Y.H. (2007). Preparation of alginate-quaternary ammonium complex beads and evaluation of their antimicrobial activity. Int. J. Biolo. Macromol., 41: 36-41.

Kumaran, S.; Radhakrishnan, M. and Balagurunathan, R. (2011). Potential bioactive compound from marine actinomycetes against biofouling bacteria. J. Adv. Biotechnol., 10: 22-26.

Manilal, A.; Selvin, J. and George, S. (2012). In vivo therapeutic potentiality of red seaweed, Asparagopsis (Bonnemaisoniales, Rhodophyta) in the treatment of vibriosis in Penaeus monodon, Fabricius. Saudi J. Biol. Sci., 19: 165-175.

Milledge, J.J.; Nielsen, B.V. and Bailey, D. (2016). High-value products from macroalgae: the potential uses of the invasive brown seaweed, Sargassum muticum. Rev. Environ. Sci. Biotechnol., 15: 67-88.

Millette, M.; Le Tien, C.; Smoragiewicz, W. and Lacroix, M. (2007). Inhibition of Staphylococcus aureus on beef by nisin-containing modified alginate films and beads. Food Control, 18: 878-884.

Mohansrinivasan, V.; Subathra, D.C.; Meenakshi, D.; Ananya, B. and Jemimah, N.S. (2015). Exploring the anticancer activity of grape seed extract on skin cancer cell lines A431. Braz. Arch. Biol. Technol., 58 (4): 540-546.

Nalini, S.; Richard, D.S.; Riyaz, M.S.U.; Kavitha, G. and Inbakandan D. (2018). Antibacterial macro molecules from marine organisms. Int. J. Biol. Macromol., 115: 696-710. 
Nazareth, A.S. and Vijayalakshmi, K. (2014). Chromatographic separation of bioactive compounds from Ipomoea batataslam (Sweet potatoes) by column, high-performance thin layer chromatography, and gas- chromatography-mass spectrum analysis Techniques. Asian J. Pharm. Clin. Res., 7 (5): 4-8.

Oliveira, S.T.L.; Veneroni-Gouveia, G.; Santos, A.C.; Sousa, S.M.N.; Veiga, M.L.; Krewer, C.C. and Costa, M.M. (2014). Ascophyllum nodosum in the diet of tilapia (Oreochromis niloticus) and its effect after inoculation of Aeromonas hydrophila. Pesqui. Vet. Bras., 34: 403-408.

Pádua, D.; Rocha, E.; Gargiulo, D. and Ramosa, A.A. (2015). Bioactive compounds from brown seaweeds: Phloroglucinol, fucoxanthin and fucoidan as promising therapeutic agents against breast cancer. Phytochem. Lett., 14: 91-98.

Paramanantham, M. and Murugesan, A. (2014). GC-MS analysis of Holarrhena antidysentrica Wall Flower. IJSETR, 3 (3): 631-639.

Parris, N.; Cooke, P.H. and Hicks, K.B. (2005). Encapsulation of essential oils in zein nanosperical particles. J. Agric. Food Chem., 53: 4788-4792.

Pasdaran, A.; Hamedi, A. and Mamedov, N. (2016). Antibacterial and insecticidal activity of volatile compounds of three algae species of Oman Sea. Int. J. Sec. Metabolite, 3 (2): 66-73.

Pérez, M.J.; Falqué, E. and Domínguez, H. (2016). Antimicrobial action of compounds from marine seaweed. Mar. Drugs, 2016, 14, 52. Doi:10.3390/md14030052

Pietro, Z.; Maurizio, S.; Maurizio, B., Antonella, M.; Sergio, R.; Carmen, F. and Felice, S. (2010). Essential oil composition of stems and fruits of Caralluma europaea N.E.Br. (Apocynaceae). Molecules, 15: 627-638.

Piola, R.F.; Dafforn, K.A. and Johnston, E.L. (2009). The influence of antifouling practices on marine invasions. Biofouling, 25: 633-644.

Rajeswari, G.; Murugan, M. and Mohan, V. R. (2013). GC-MS analysis of bioactive components of Hugonia mystax L. bark (Linaceae). J. Pharm. Biomed. Sci., 29 (29): 818-824.

Randhawa, G.K. and Kullar, J.S. (2011). Bioremediation of pharmaceuticals, pesticides, and petrochemicals with gomeya/cow dung. ISRN Pharmacol., doi: $10.5402 / 2011 / 362459$

Redjem, Y.B.; Ktari, L.; Medhioub A.A. and El Bour, M. (2013). Antibacterial and algicidal properties of some brown seaweeds from Northern coasts of Tunisia. Vie et Milieu., 63(3): 127-133.

Rizzo, C.; Genovese, G.; Morabito, M.; Faggio, C.; Pagano, M.; Spanò, A.; Zammuto, V.; Minicante, S.A.; Manghisi, A.; Cigala, R.; Crea, F.; Marino, F. and Gugliandolo, C. (2017). Potential antibacterial activity of marine macroalgae against pathogens relevant for Aquaculture and human health.J. Pure. Appl. Microbiol., 11(4): 1695-1706.

Saha, M., Goecke, F., Bhadury, P. 2017. Minireview: algal natural compounds and extracts as antifoulants. J. Appl. Phycol., 30(1): doi:10.1007/s10811-017-13220

Saleh, B. and Al-Mariri, A. (2017). Antimicrobial activity of the marine algal extracts against selected pathogens. J. Agr. Sci. Tech., 19: 1067-1077.

Sanjeewa, K.K.A.; Kim, E.A.; Son, K.T. and Jeona, Y.J. (2016). Bioactive properties and potentials cosmeceutical applications of phlorotannins isolated from brown seaweeds: a review. J. Photochem. Photobiol. B, 162: 100-105. 
Save, S.A.; Lokhande, R.S. and Chowdhary, A.S. (2015). Determination of 1, 2benzenedicarboxylic acid, bis (2-ethylhexyl) ester from the twigs of Thevetia peruviana as a colwell biomarker. JIPBS, 2 (3): 349-362.

Sethi, A.; Prakash, R.; Amandeep; Shukla, D.; Bhatia, A. and Singh, R.P. (2013). Identification of phytochemical constituents from biologically active pet ether and chloroform extracts of the flowers of Allamanda violacea A.DC (Apocynaceae). Asian J. Plant Sci. Res., 3(4): 95-108.

Shobier, A.H.; Abdel Ghani, S.A. and Barakat, K.M. (2016). GC/MS spectroscopic approach and antifungal potential of bioactive extracts produced by marine macroalgae. Egypt. J. Aquat. Res., 42: 289-299.

Shobier, A.H.S.; Wefky, S.; Abdel Ghani, S.A. and El Ashry, E.S.H. (2010). Comparative study of the antibacterial activity of Ulva lactuca and Pterocladia capillacea extracts before and after encapsulation in Ca-alginate beads. Egypt. J. Aquat. Res., 36 (3): 395-402.

Sivakumar, S.R. (2014). GC-MS analysis and antibacterial potential of white crystalline solid from red algae Portieria hornemannii against the plant pathogenic bacteria Xanthomnas axonopodis pv. Citri (Hasse) Vauterin et al. and Xanthomonas campestris pv. Malvacearum (smith 1901) dye 1978b. Int. J. Adv. Res., 2: 174-183.

Stabili, L.; Acquaviva, M.I.; Biandolino, F.; Cavallo, R.A.; De Pascali, S.A.; Fanizzi, F.C.; Narracci, M.; Cecere, E. and Petrocelli,. A. (2014). Biotechnological potential of the seaweed Cladophora rupestris (Chlorophyta, Cladophorales) lipidic extract. New Biotechnol., 31: 436-444.

Stalin, S.I.; Kiruba, S. and Das, S.S.M. (2008). A comparative study in the toxicity of a synthetic pyrethroid Deltamethrin and a neem based pesticide Azadirachtin to Poecilia reticulate Peters 1859 (Cyprinodontiformes: Poeciliidae). Turk. J. Fish. Aquat. Sci., 8: 1-5.

Sudha, T.; Chidambarampillai, S. and Mohan, V.R. (2013). GC-MS Analysis of bioactive components of Aerial parts of Fluggea leucopyrus Willd. (Euphorbiaceae). J. Appl. Pharm. Sci., 3 (5): 126-130

Tomazelli Jr. O.; Kuhn, F.; Padilha, P.J.M.; Vicente, L.R.M.; Costa, S.W.; Silva, B.C.; Schleder, D.D.; Boligon, A.A.; Scapinello, J.; Nesi, C.N.; Dal Magro, J. and Castellví, S.L. (2017). Effect of Cynodon dactylon extract on white spot virus-infected Litopenaeus vannamei. Aquacult. Int., 25: 1107-1122.

Trigui, M.; Gasmi, L.; Zouari, I. and Tounsi, S. (2013). Seasonal variation in phenolic composition, antibacterial and antioxidant activities of Ulva rigida (Chlorophyta) and assessment of antiacetylcholinesterase potential. J. Appl. Phycol., 25: 319-328.

Uma Maheswari, M. and Reena, A. (2017). Phytochemical profiling of the red seaweed, Halymenia dilatata by GC-MS analysis. Int. J. Pharm. Sci. Res., 8 (8): 167-172.

Vatsos, I.N. and Rebours, C. (2015). Seaweed extracts as antimicrobial agents in aquaculture. J. Appl. Phycol., 27: 2017-2035.

Wan, A.L.; Davies, S.; Soler-Vila, A.; Fitzgerald, R. and Johnson, M.P. (2018). Macroalgae as a sustainable aquafeed ingredient. Reviews. Aquaculture, 1-35, doi: 10.1111/raq.12241

Wang, L., Park, Y.-J., Jeon, Y.-J. and Ryu, B. (2018). Bioactivities of the edible brown seaweed, Undaria pinnatifida: A review. Aquaculture, 495: 873-880. 
Ward, D.; Bengtson, D.A.; Lee, C.M. and Gomez-Chiarri, M. (2016). Incorporation of soybean products in summer flounder (Paralichthys dentatus) feeds: effects on growth and survival to bacterial challenge. Aquaculture, 452: 395-401.

Wefky, S.; Shobier, A.H.S.; Abdel Ghani, S.A. and El Ashry, E.S.H. (2009). Screening of the antibacterial activity of some marine algae against fish and human pathogens. Bull. High Inst. Pub. Health, 39: 112-124.

Wong, Y.H. and Kadir, H.A. (2011). Leea indica ethyl acetate fraction induces growth-inhibitory effect in various cancer cell lines and apoptosis in Ca Ski human cervical epidermoid carcinoma cells. Evid- Based Complement. Alternat. Med., 2011:293060. Doi: 10.1155/2011/293060.

Ye, W.; Leung, M.F.; Xin, J.; Kwong, T.L.; Lee, D.K.L. and Li, P. (2005). Novel core-shell particles with poly(n-butyl acrylate) cores and chitosan shells as an antibacterial coating for textiles. Polymer, 46:10538-10543

Yebra, D.M.; Kiil, S. and Dam-Johansen, K. (2004). Antifouling technology-past, present and future steps towards efficient and environmentally friendly antifouling coatings. Progr. Org. Coat., 50: 75-104.

Zheng, C.J.; Yoo, J.S.; Lee, T.G.; Cho, H.Y.; Kim, Y.H. and Kim, W.G. (2005). Fatty acid synthesis is a target for antibacterial activity of unsaturated fatty acids. FEBS Lett., 579: 5157-62.

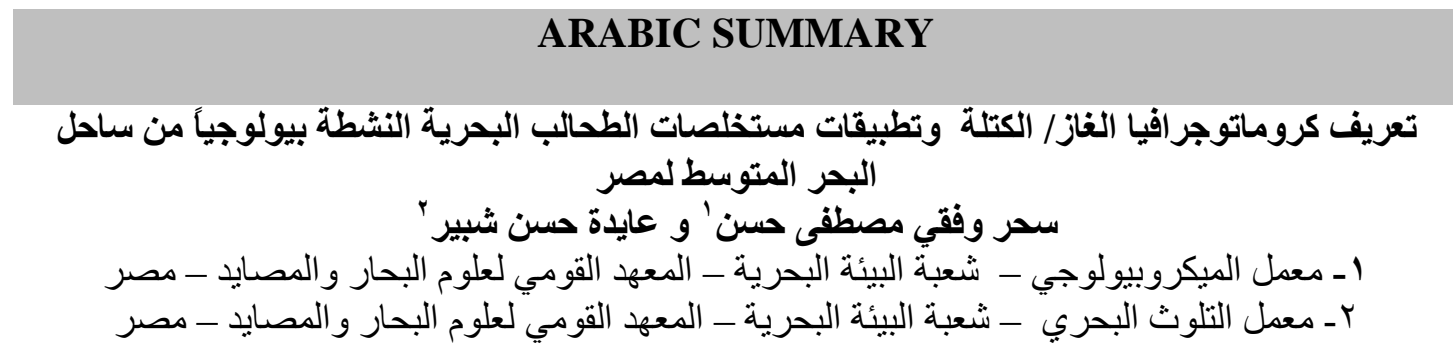

تم في هذه الدراسة تعيين النشاط المضاد للبكتيريا لأنواع مختلفة من الطحالب البحرية ضد خمس Vaphasta

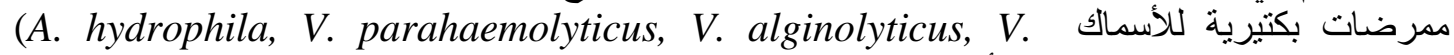
damsela, Vibrio sp.)

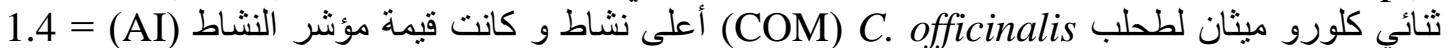

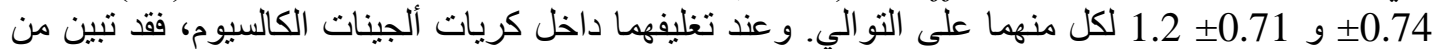


parahaemolyticus

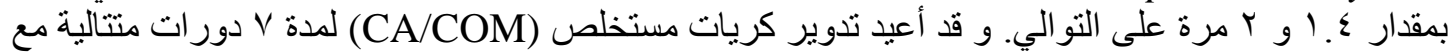

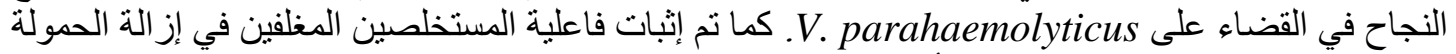

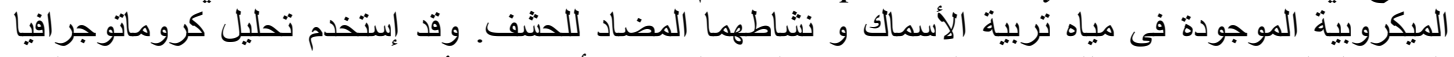



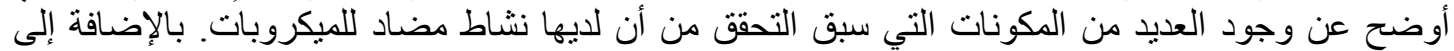

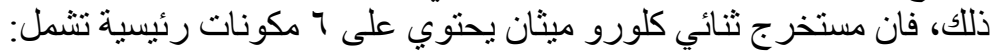
n-nonadecane, 1,2,3-propanetricarboxylic acid, 2-(acetyloxy)-, tributyl ester, 2methylhexadecan-1-ol, 1-docosene, 1-eicosanol and chloroacetic acid, octadecyl ester.

بينما تميز المستخلص الإيثانولي (CSE1) بوجود أحماض دهنية و إسترات إيثيل الأحماض الدهنية

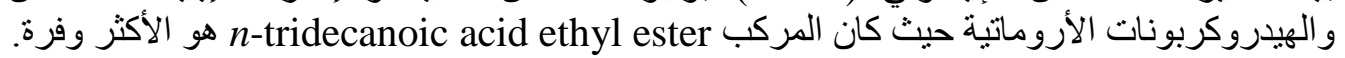

